\title{
The Role of Notary and PPAT in Making Inheritance Deed for Non-Muslim Heirs Adri Aulia Rahman", Shalim HS ${ }^{* *}$, Muhaimin ${ }^{* *}$ \\ "Postgraduate program Legal Study and Notaries, Mataram University, Indonesia \\ *** Lecture of Law Faculty Mataram University, Indonesia
}

\begin{abstract}
The problem of inheritance is still a complex matter in Indonesia. In general, the transfer of inheritance is carried out in several ways, namely inheritance, grant and will. Provisions regarding inheritance are regulated in the Civil Code, KHI and various jurisprudences which can be used as a foundation. In carrying out the distribution of inheritance is also inseparable from the role of Notary and PPAT which by Law Number 30 of 2004 concerning Notary Position and Government Regulation Number 37 of 1998 concerning PPAT Position Regulations, the regulation is given the authority to make deeds. The method used in the study is the empirical research method. In order to find out the position of non-Muslim heirs in Islamic inheritance, and to find out how the role of Notary and PPAT and the form of deed made in the distribution of the inheritance.
\end{abstract}

Keywords: inheritance, notary and PPAT, deed

\section{Introduction}

Inheritance is one of the most complex problems to date. The enactment of Islamic law in Indonesia is not only based solely on historical reasons but also the reality of society in Indonesia is heterogeneous or in other terms pluralist. ${ }^{1}$ Suparman Usman said that Indonesia is a very diverse legal country for all cultures. In legal developments that occur in Indonesia, Islamic law includes being a source of law in Indonesia. ${ }^{2}$

The transfer of ownership rights to the heir's inheritance is only limited to the property that is inherently owned by the heir during his lifetime, namely in the form of activity including the inheritor's receivables. As for the inheritance in the form of Debt (liability), it does not participate in giving an award to the heirs. The inheritor's debts are borne and dealt with from and as long as the inheritance's inheritance in an active form is sufficient for that, as intended by the provisions of Article 175 paragraph (2) Compilation of Islamic Law ${ }^{3}$ which reads: "The heir's responsibility for the debt or the heir's liability is limited to the amount or value of his inheritance".

Islamic policy is certainly different from the Dutch inheritance legal system transferred to Indonesia in the form of the Civil Code (BW), which contains the principle that if the heir dies in a debt (liability) then the heirs are entitled to resign as heirs . But on the contrary if the heir leaves property without debt (activa) or has a debt but his assets are sufficient to pay off the debt or even more, then an heir can declare as heir.

The Wajibah Testament Concept is a development of the concept of inheritance in Islam. Giving through obligatory wills is of course given to those who cannot receive inheritance or because they are veiled.

As for those who have the right to receive a compulsory will, according to Ibn Hazmin are relatives who do not receive inheritance, whether because they are slaves or because of different religions with heirs, or because he is hijab inherited because there are relatives or other heirs that prevent him, or because he not

\footnotetext{
${ }^{1}$ M. Fahmi Al Amruzi, Rekonstruksi Wasiat Wajibah dalam Kompilasi Hukum Islam, Aswaja Pressindo, Yogyakarta, 2012, p. 3

${ }^{2}$ Suparman Usman, Hukum Islam; Asas-Asas Pengantar Studi Hukum Islam dalam Tata Hukum Indonesia, Gaya Media Pratama, Jakarta, 2001, p. 122

${ }^{3}$ Compilation of Islamic Law is the Presidential Instruction (INPRES) Number 1 of 1991 which contains three books, namely Book I Marriage Law, Book II Inheritance Law, and Book III Perwakafan Law. Which is the material law of the Religious Court and the Mahkamah Syar'iyah.
} 
entitled to inherit. ${ }^{4}$ For them, they should be wise; if the heir is not intellectually the heirs must give them the inheritance according to them accordingly. Likewise for relatives who are not Muslim, the heir must be intimate for them and if the heir is not intellectually, then part of the heir's inheritance must be given to the relatives of different religions.

Therefore, the implementation of a will is closely related to the duties of the notary profession as mandated by the Act of Notary Position. Against a will from those who will make a will can be stated in an authentic deed, so that they will have perfect proof power.

\section{Result And Discussion}

\subsection{Position of Non-Muslim Heirs in the Distribution of inheritance}

The difference in religion as a barrier to inherit in inheritance law in accordance with the content of the hadith is indeed irreversible, but certainly in subsequent developments when the socio-cultural reality has been different from the time when the hadith was revealed it should be distinguished from proven murder or slander or recognized by the perpetrators who are universally recognized with crimes against humans, so that if the perpetrators are punished cannot inherit the heirs who are killed, persecuted, or slandered, then no one will claim that Islamic law is unfair.

Religious differences are not crimes against humanity but concerning beliefs in the truth of the teachings of Islam have taught this. Therefore if the heirs of different religions with their heirs who are Muslim do not get a share, then Islamic law will be considered as an unfair law.

It is stated in the Qur'an the Al-Baqarah verse 180 which means that if a person is not an inheritance, the living relatives are obliged to issue a certain amount of inheritance which they deem appropriate for relatives who are not entitled to inherit.

Regarding the position of non-Muslim heirs (apostates and / or non-Muslims) in the distribution of nonexistent inheritance is regulated in the Compilation of Islamic Law. In the Civil Code does not regulate the provision of inheritance that is intended for a particular religion or belief, this is because the Civil Code does not distinguish between certain religions or beliefs in matters of inheritance. However, the position of non-Muslim heirs (apostates and / or non-Muslims) in the distribution of inheritance by a judge's decision can be given with the concept of a mandatory will. As the concept of obligatory testament is an effort of ijtihad among Islamic law experts which subsequently becomes the judge's reference in making legal discoveries, rechtsvinding judges must provide their legal decisions within a reasonable time period, ${ }^{5}$ in its decision based on justice. As the Decision of the Supreme Court of the Republic of Indonesia Number: 368K/AG/1995, dated July 16, 1998 and subsequently the Decision of the Supreme Court of the Republic of Indonesia Number: 51K/AG/1999, dated September 29, 1999 which essentially granted non-Muslim heirs the right to inherit fundamental in mandatory wills.

\subsection{The Role of Notaries and PPATs in Making the Deed of Distribution of Inheritance to Non-Muslim Heirs}

Based on Article 1 paragraph (3) of the 1945 Constitution, a Director General of Agrarian Letter was issued on behalf of the Minister of Home Affairs dated December 20, 1969 No. Dpt/12/63/12/69 concerning Legacy Certificate and proof of citizenship for Jo. Article 42 paragraph (1) PP No. 24 of 1997 concerning Jo Land Registration. Provisions of Article 111 paragraph (1) letter c Regulation of the Head of the National Land Agency No. 8 of 2012 concerning Land Registration (PerKaBan No. 8 of 2012), can be made in the form of a certificate of inheritance rights whose authority to make it is distinguished based on race and population. The classification includes: ${ }^{6}$

1. For Indigenous citizens; Certificate of Heir made by the heirs witnessed by 2 (two) witnesses and confirmed by the Village Head or Sub-District and Sub-District Head where the heir lives at the time of death.

2. For Indonesians of Chinese descent; Deed of Certificate of inheritance from a Notary.

3. For other foreigners of East Indonesian origin; Certificate of inheritance from the Heritage Office.

\footnotetext{
${ }^{4}$ Ibnu Hazm, al-Muhalla, Daarul Fikri, Bairut.

5 J.A. Pontier, Rechtsvinding, Cip Gegevens Konnklijke Bibliotheek, Den Haag, 1988, p. 1

${ }^{6}$ Sonny Tobelo Manyawa, Warisan dan Wasiat, Http://sonny-tobelo.blogspot.com/2011, accessed on January 29, 2019.
} 
Law Number 2 Year 2014 changes to Law Number 30 Year 2004 concerning Notary Position hereinafter referred to as UUJN explains in Article 1 number (1), a Notary is a General Officer authorized to make authentic deeds and other authorities as referred to in this Law . Then in Government Regulation Number 24 Year 2016 changes to Government Regulation Number 37 of 1998 concerning Position Regulations of Land Deed Officials in Article 1 explain that Land Acting Officials (PPAT) are public officials who are authorized to make authentic deeds regarding legal acts certain concerning rights to land or ownership rights to apartment units. From the definition, it can be said that the position of Notary and PPAT is a position as a General Officer whose authority is given in making authentic deeds. So that the authority both the deed made by the Notary and the PPAT is an authentic deed, for the authenticity, the deed of the Notary and PPAT has perfect proof power.

PPAT as a public official who is also given the authority to make authentic deeds as stipulated in PP No. 24 of 2016 changes to PP 37 of 1998 concerning the position of PPAT actually has more specific authority regarding everything or certain legal actions regarding registration of land rights, Article 2 paragraph (1) PP 37 of 1998 concerning PPAT Position Regulations.

From the results of field observations by the compilers in the Notary and PPAT offices, Notaries and PPATs argue that in making the deed of certificate of deed based on the obligatory will made in the form of a will. However, the notary also believes that the deed or statement of inheritance or made is irrespective of religion or the beliefs of the parties who have interests in terms of inheritance. This is because both the Notary and the PPAT only make a will based on the interests of the parties.

So, in the case of the implementation of inheritance distribution for non-Muslim heirs, the notary has a role in making a will not only a mandatory will, which is a compulsory concept of inheritance for non-Muslim heirs that is strengthened based on a court decision that has the power permanent law. As also in the Civil Code in Article 938 Jo. 940 explains that a will with a general deed must be made before a notary and two witnesses and a notary must make an explanatory deed regarding a closed or confidential will. So in the distribution of inheritance for non-Muslim heirs, the gift is through a Testament deed made by a notary.

2.3 Form of Deed Made by Notary and PPAT in the case of distribution of inheritance for non-Muslim heirs

The position of a notary as a position given authority by law in making a deed certainly has a strong evidentiary power of the product deed made by the notary. When referring to the form and function of the Notary deed specifically it has been regulated in Article 38 of Act Number 30 of 2004 concerning Notary Position. The formulation of the article concerning the form and nature of the notary deed includes the following:

1) Each Notary deed consists of:

a. Beginning of deed or head of deed;

b. Deed body; and

c. End or closing deed.

2) The beginning of the deed or head of the deed contains:
a. Title of deed;
b. Deed number;
c. Hours, days, dates, months and years; and
d. Full name and place of residence of the Notary.

3) The deed body includes:

a. Full name, place and date of birth, nationality, occupation, position, position, residence of the occupants and / or the person they represent;

b. Information about the position of acting viewers;

c. The contents of the deed which are wishes and desires of the concerned parties; and

d. Full name, place and date of birth, as well as occupation, position, position and residence of each identifying witness.

4) The end or closing of the deed contains:

a. A paragraph $16(7)$;

b. A description of the signing and signing or translating the deed if any;

c. Full name, place and date of birth, occupation, position, position and residence of each witness deed; 
d. A description of the changes that have occurred in any changes that can be in the form of additions, deletions or replacements.

The provisions in Article 38 of the UUJN are the conditions that must be fulfilled as a notary deed. ${ }^{7}$ If connected with the provisions of Article 1868 of the Civil Code of Article 1869 of the Civil Code which is the source of authenticity of the notary deed and also as the legality of the existence of a notary deed. In the Notary Position Regulation, the head of the deed only contains statements or mentioning the place of position of the Notary and the names of the parties who come or face the Notary, and in Article 38 paragraph (2) UUJN the head of the deed contains the title of the deed, ${ }^{8}$ deed number, hour, day, date, month and year; and the full name and place of residence of the Notary.

So the deed form used by a Notary in the case of inheritance distribution for non-Muslim heirs is in the form of a will, as explained in the previous discussion. However, in particular the form of the deed must refer to the provisions of Article 38 of the Notary Position Act, in which the provisions concerning the form of a notary deed consist of the beginning of the deed or head of the deed, the Act and End deed or closing deed.

\section{Conclusion}

Giving inheritance to non-Muslim heirs in Islam is not regulated in the Civil Code and Compilation of Islamic Law (KHI). However, the position of non-Muslim heirs (apostates and / or non-Muslims) in the distribution of inheritance by a judge's decision can be given with the concept of a mandatory will. As the Decision of the Supreme Court of the Republic of Indonesia Number: 368K/AG/1995, dated July 16, 1998 and subsequently the Decision of the Supreme Court of the Republic of Indonesia Number: 51K/AG/1999, dated September 29, 1999 which essentially granted non-Muslim heirs the right to inherit fundamental in mandatory wills.

From the results of field observations by the compilers in the Notary and PPAT offices, Notaries and PPATs argue that in making the deed of certificate of deed based on the obligatory will made in the form of a will. However, the notary also believes that the deed or statement of inheritance or made is irrespective of religion or the beliefs of the parties who have interests in terms of inheritance. This is because both the Notary and the PPAT only make a will based on the interests of the parties.

The form of deed used by a Notary in the case of inheritance distribution for non-Muslim heirs is in the form of a will, as explained in the previous discussion. However, specifically the form of the deed must refer to the provisions of Article 38 of the Notary Position Act, in which the provisions concerning the form of a notary deed consist of the beginning of the deed or head of the deed, the Act and End deed or closing of the deed.

\section{References}

\section{Books}

[1] Al Amruzi M. Fahmi. 2012. Rekonstruksi Wasiat Wajibah dalam Kompilasi Hukum Islam. Aswaja Pressindo, Yogyakarta

[2] Hazm Ibnu, al-Muhalla. Daarul Fikri, Bairut.

[3] Lumbang Tobing G.H.S. 1980. Peraturan Jabatan Notaris. Erlangga, Jakarta.

[4] Pontier J.A. 1988. Rechtsvinding, Cip Gegevens Konnklijke Bibliotheek, Den Haag.

[5] Usman Suparman. 2001. Hukum Islam; Asas-Asas Pengantar Studi Hukum Islam dalam Tata Hukum Indonesia. Gaya Media Pratama, Jakarta.

\section{Regulations}

[1] Civil Code (Civil Code)

[2] Law Number 30 of 2004 concerning Notary Position

[3] Compilation of Islamic Law

${ }^{7}$ Article 1 number (7) UUJN.

${ }^{8}$ G.H.S Lumbang tobing, Peraturan Jabatan Notaris, Erlangga, Jakarta, 1980, p. 214 
[4] Government Regulation Number 37 of 1998 concerning Position Regulations for Land Deed Officials 